Digital Press Social Sciences and Humanities

Bandung City as A Sundanese Gastronomy Foodscape

Dewi Turgarini

Proceeding of Indonesia Heritage Tourism Forum 2019 (IHTF 2019)

Dewi Pratika Ayu Dhira Pradati (eds) 


\title{
Bandung City as A Sundanese Gastronomy Foodscape
}

\author{
Dewi Turgarini* \\ Universitas Pendidikan Indonesia, Bandung, Indonesia \\ *e-mail: dewiturgarini@upi.edu
}

\begin{abstract}
Food landscape or foodscape is a spatial distribution of food, the location where food is served to be bought and consumed, or the space associated with food and eating, including food consumption services. Foodscape is important as a supporter of gastronomic tourism in Bandung. This research was conducted to examine foodscape and food supply lines for gastronomic tourism activities in Bandung. The research was conducted by observation and survey methods. The results showed the entire of Bandung was a foodscape as well as a Sundanese gastronomic estuary, with a spread of food ranging from markets, street vendors, food stalls and restaurants, festival events to educational institutions which were an area to bring together Sundanese gastronomic products with their consumers. The foodstuffs have flowed from foodshed around Java, Sumatra, Kalimantan, Sulawesi, and even from China. Food raw materials were transmitted from several regions in West Java through the local food network.
\end{abstract}

\section{Keywords}

foodscape, gastronomy, Bandung

\section{Introduction}

Bandung, since the colonial era, is known as an urban tourism destination. The city tour has a unique blend of urban physical landscape with socio-cultural communities, especially local gastronomic activities of the Sundanese ethnic, so that it is relatively different from other cities in Indonesia, especially those in Java, such as Jakarta, Yogyakarta, Semarang, Surabaya and Malang (Table 1), even with Papuan gastronomy and so on.

Table 1 Comparison of Tourist Destination for Cities in Java

\begin{tabular}{|c|c|c|c|c|c|c|}
\hline Item & Jakarta & Yogyakarta & Semarang & Surabaya & Malang & Bandung \\
\hline $\begin{array}{l}\text { Dominant } \\
\text { Ethnic }\end{array}$ & Javanese & Javanese & Javanese & Javanese & Javanese & Sundanese \\
\hline Landscape & Coastal & Land & Coastal & Coastal & Mountain & Mountain \\
\hline $\begin{array}{c}\text { Tourism } \\
\text { Brand }\end{array}$ & Shopping & Craft & Architectural & Historical & $\begin{array}{c}\text { Fruit } \\
\text { Garden }\end{array}$ & $\begin{array}{l}\text { Creative } \\
\text { Culinary }\end{array}$ \\
\hline City Image & Metropolis & Education & Marine & Revolution & Education & $\begin{array}{l}\text { Culinary } \\
\text { Tourism }\end{array}$ \\
\hline $\begin{array}{c}\text { City's } \\
\text { Nickname }\end{array}$ & Metropolitan & $\begin{array}{l}\text { The City of } \\
\text { Gudeg }\end{array}$ & Venetië van Java & $\begin{array}{l}\text { Kota Pahlawan } \\
\text { (The City of } \\
\text { Heroes) }\end{array}$ & $\begin{array}{l}\text { Kota Apel } \\
\text { (The City of } \\
\text { Apple) }\end{array}$ & Parijs Van Java \\
\hline
\end{tabular}

A food-based form of gastronomic tourism (gastro-tourism), and has now become an important factor in the development of a cultural tourism market (Soeroso \& Susilo, 2013; Turgarini \& Soeroso, 2014). According to Thorne (2001), more and more holidaymakers are eager to increase horticultural knowledge 
and cooking skills in local communities. Likewise, tourists who come to Bandung tend to initiate food (Sumaryadi \& Pah, 2010). Unfortunately, the attractiveness of food, especially gastronomic based on Sundanese ethnicity, has not yet become a tourism pillar in Bandung. The food presented is still seen as fulfilling physical needs and sometimes as gifts, so that it is less well-known than imported food such as chicken served by KFC or McDonald's outlets, whereas local-traditional gastronomy has become an international attraction that attracts tourists in tourist cities like Vlora in Albania (Brokaj, 2014), Barcelona in Spain, Venice in Italy (Mason \& Paggiaro, 2012), Melbourne in Australia (Edwards \& Mercer, 2010) and others. Foodscape in these countries supports local-traditional gastronomic events so that the actors can broadly collaborate to offer visitors experience. In connection with this, the focus of this research is to examine foodscape and food supply lines for gastronomic tourism activities in Bandung.

Gastronomy as shown in Fig. 1, basically does not only focus on culinary arts that focus on the kitchen and cooking, processing recipes into food done by cooks (Dictionary.com, n.d.; Kamus Besar Bahasa Indonesia, n.d.). Gastronomy, according to Lilholt (2015), specifically includes all cooking techniques, nutrition, food science, and everything that has to do with delicacy, taste, and aroma when consuming food. Gastronomy is more related to human behavior in treating food, including in selecting raw materials, tasting, feeling, serving food, to finding and obtaining the experience of consuming and studying, researching and writing about food and all things related to ethics, etiquette and nutrition human (Lilholt, 2015; Manolis, 2010; Pullphothong \& Sopha., 2013; Santich, 1996; Shenoy, 2005; Soeroso, 2014). Thus, gastronomy is an art and science, even an appreciation that is cross-ethnic, national, racial, group, religious, gender, and cultural by studying in detail on eating, food, and drinks for use in various conditions and situations.

Meanwhile, food landscape or "foodscape" according to some literature is defined as the spatial distribution of food (Johnston, Biro, \& MacKendrick, 2009; Sobal \& Wansink, 2007; Winson, 2004), the location where food is served for purchase and consumption (Brembeck \& Johansson, 2010), or spacerelated to food and eating, including services on food consumption (Winson, 2004). Foodscape can also be a community structure that forms the food environment (Burgoine et al., 2009). Even Johnston et al. (2009) call it an ecological site and a production system, chain, ethics, and food policy (Freidberg, 2010) including its institutional arrangements (Sobal \& Wansink, 2007). Therefore, foodscape is a socio-cultural construction of the relationship of food systems and products, with space as well as attributes and meanings where food is consumed, or explored (Knasko, Gilbert, \& Sabini, 1990; Sobal \& Wansink, 2007; Winson, 2004; Zukin, 1991); or according to Dolphijn (2005) is a process of interaction between food (what), place or space (where) and consumers (by whom).

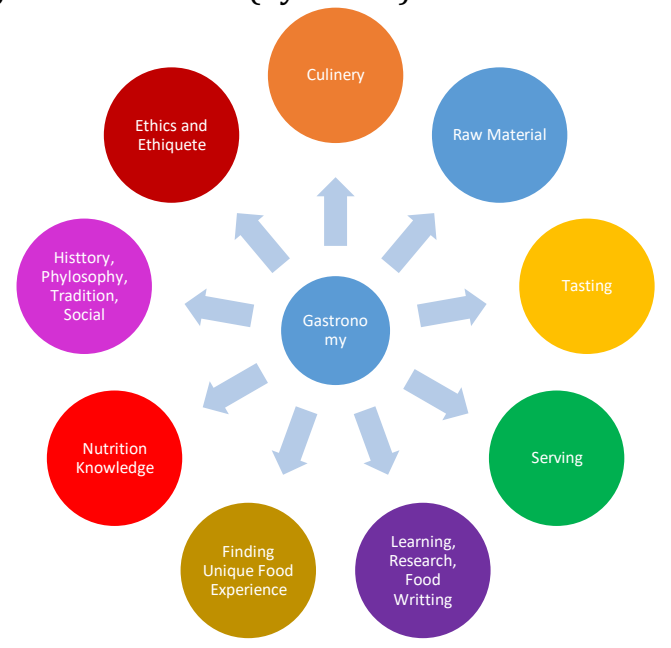

Fig. 1 Gastronomy

Source: Turgarini (2018) processed from Shenoy (2005), Manolis (2010), Santich (1996),

Pullphothong \& Sopha (2013), (Soeroso, 2014)

Wenzer (as cited by Dolphijn, 2005, p. 155) states that eating is an integral part of foodscape so that one actor acts as an eater, and the other becomes his food. Foodscape is a food landscape that deals with a long chain of food transmission and distribution channels, starting from the source or origin and environment of raw materials (which affect the aroma, taste, color of food), production systems, institutions, human behavior (producers and consumers ) until the location are consumed. Therefore, as part of human culture, 
food and gastronomy cannot be separated. Foodscape is a part of gastronomy, and gastronomy requires foodscape so it is an important aspect of gastronomic tourism success.

Foodscape is considered important for gastronomy development because there are activities that cause products to be available for consumption. Gastronomic entrepreneurs will choose a strategic location to deliver products to customers and try to attract them to consume them. Foodscape will affect the target market, competition, and business costs. Location is a very important element for consumers to recognize the place of business (in this context of gastronomy). A strategic location in the foodscape is also a competitive advantage that is not easy to imitate (Karadeniz, 2009). It is the foodscape factor that is suspected to cause Sundanese gastronomy to be unable to compete with imported snack products.

Another part of the foodscape that is considered necessary to see is the food product transmission line. The successful partnership between producers and retailers in the gastronomic tourism business depends on the transmission of goods from the origin to the outlet. For local gastronomy, this chain involves the role of growers, intermediary traders, wholesalers, input suppliers, and retailers. The main processes include harvesting, storage, packaging, shipping transportation, and so on. Effective transmission in the foodscape needs continuities and reduces risk and uncertainty by ensuring the right amount, condition, time, cost, location (Gebresenbet \& Basola, 2012). So, the transmission line is one part of the foodscape that is important in supporting gastronomic tourism. Disruption of foodscape especially in the transmission line causes chaos between producer and consumer relations. If this transmission line is well developed, in the future it can become an attractive travel food.

\section{Methods}

\subsection{Research Location}

The research location is in Bandung, an urban area which morphology is divided into two parts, in the north is a mountainous area with an altitude between 768-1050 meters above sea level, while in the south it is relatively lower with an altitude of 675 meters above sea level. The Bandung is the administrative center of the area (tatar) Pasundan which has 30 sub-districts and 153 villages.

\subsection{Data}

Data collection in this study was conducted by observation and survey. This study used data: (1) primary and (2) secondary. Primary data were collected directly by researchers from the results of interviews with samples or respondents through observation and survey (Bryman, 2012; Currie, 2005; Somekh \& Lewin, 2004). Samples were people who were taken non-probability (non-probability sampling) using purposive techniques or often also called judgmental sampling. There were 360 people as samples. For sharpening the results of the study, brainstorming, expert meetings (expert meetings), and focus group discussions (FGD) were conducted.

Other data were secondary, extracted from relevant agencies or institutions such as the Office and other Offices in the Bandung City Government and the West Java Provincial Government, Ministry of Tourism, Ministry of Education and Culture, Ministry of Public Works, LIPI, as well as various literature, books, scientific publications, etc.

\section{Finding and Discussion}

Based on the research results demonstrated the available food sources, food transmission lines from the origin, both regarding the location and type of food, to Bandung, and the available food in Bandung. 


\subsection{Food Sources}

Food sources for communities and businesses in Bandung include rice, corn, peanuts, cassava, and sweet potatoes (Table 2). Then also horticultural crops such as vegetables (Table 3) and fruits (Table 4) (BPS Kota Bandung, 2018).

Table 2 Planting Area, Harvest, Production and Food Crop Productivity

\begin{tabular}{llrrrr}
\hline Food Crop & \multicolumn{1}{c}{ Latin Name } & $\begin{array}{c}\text { Planting Area } \\
(\mathrm{Ha})\end{array}$ & $\begin{array}{c}\text { Harvesting Area } \\
(\mathrm{Ha})\end{array}$ & $\begin{array}{c}\text { Production } \\
(\mathrm{Ton})\end{array}$ & $\begin{array}{c}\text { Productivity } \\
(\mathrm{Kw} / \mathrm{Ha})\end{array}$ \\
\hline Dry rice & Oryza sativa & $1,704.00$ & $1,688.40$ & $103,257.00$ & 61.10 \\
Corn & Zea mays & 44.00 & 36.00 & 952.38 & 24.50 \\
Peanuts & Arachis hypogaea $L$ & 14.00 & 12.00 & 149.88 & 12.50 \\
Cassava & Manihot utilissima & 58.00 & 18.00 & $2,808.00$ & 156.00 \\
Sweet potato & Ipomoea batatas $L$ & 42.50 & 14.00 & $1,243.48$ & 88.80 \\
\hline
\end{tabular}

The raw material for self-produced food certainly could not meet the needs of the community, especially for tourism purposes. The shortage of various foodstuffs, including fruits, was often brought in from outside the region, even abroad.

Table 3 Fruits Produced by Bandung 2016

\begin{tabular}{cllc}
\hline No & Type of Commodity & \multicolumn{1}{c}{ Latin Name } & Production (Kw) \\
\hline 1 & Avocado & Persea Americana & 10 \\
2 & Mango & Mangifera indica & 126 \\
3 & Banana & Musa sp. & 460 \\
4 & Rambutan & Nephelium lappaceum & 2 \\
5 & Guava & Syzygium aqueum & 10 \\
6 & Jackfruit & Artocarpus heterophyllus & 2 \\
7 & Breadfruit & Artocarpus communis & 155 \\
\hline
\end{tabular}

Table 4 Vegetables Produced by Bandung 2016

\begin{tabular}{|c|c|c|c|c|c|}
\hline No & Type of Commodity (Ha) & Latin Name & $\begin{array}{c}\text { Planting Area } \\
(\mathrm{Ha})\end{array}$ & $\begin{array}{l}\text { Production } \\
(\mathrm{Kw} / \mathrm{Ha})\end{array}$ & Harvest per Ha \\
\hline 1 & Onion String & Allium fistulosum & 9.00 & 216.00 & 24.00 \\
\hline 2 & Spinach & Amaranthus sp. & 7.00 & 36.00 & 5.14 \\
\hline 3 & Big Chili & Capsicum annum & 4.00 & 10.00 & 2.50 \\
\hline 4 & Cayenne & Capsicum frutescens & 4.00 & 108.00 & 27.00 \\
\hline 5 & Red Bean & Phaseolus vulgaris & 7.00 & 16.00 & 2.29 \\
\hline 6 & Long Bean & Vigna unguiculata & 7.00 & 20.00 & 2.86 \\
\hline 7 & Water Spinach & Ipomoea aquatica & 12.00 & 171.00 & 14.25 \\
\hline 8 & Cauliflower & Brassica oleracea var. botrytis & 9.00 & 238.00 & 26.44 \\
\hline 9 & Cucumber & Cucumis sativus & 7.00 & 154.00 & 22.00 \\
\hline 10 & Cabbage & Brassica oleracea var. capitata & 9.00 & 251.00 & 27.89 \\
\hline 11 & Carrot & Daucus carota & 2.00 & 86.00 & 43.00 \\
\hline 12 & Radish & Raphanus raphanistrum & 3.00 & 25.00 & 8.33 \\
\hline 13 & Chinese Cabbage & $\begin{array}{c}\text { Brassica rapa subsp. } \\
\text { pekinensis }\end{array}$ & 16.00 & 165.00 & 10.31 \\
\hline 14 & Tomato & Solanum lycopersicum & 2.00 & 27.00 & 13.50 \\
\hline
\end{tabular}




\subsection{Foodscape Stage}

Bandung has 40 traditional markets as foodscape which are divided into classes 1 , 2, and 3 . Ten famous traditional markets in Bandung are presented in Table 5. These markets are where 26,075 traders make a living (BPS Kota Bandung, 2018). Sundanese food raw material from various regions, both around West Java and from other regions in the country and abroad, are sent to these traditional markets before being distributed to consumers.

Table 5 Vegetables Produced by Bandung 2016

\begin{tabular}{rlll}
\hline No & Traditional Market & Address & Operational Time \\
\hline 1 & Cihapit & Jln Cihapit, Bandung Wetan & $06.00-17.00$ \\
2 & Kordon & Jln Terusan Ibrahim Adjie, Kujangsari, Bandung Kidul & $07.30-1830$ \\
3 & Simpang Dago & Jln Ir. H. Djuanda, Dago Coblong & $08.00-2100$ \\
4 & Kosambi & Jln Ahmad Yani, Kebon Pisang, Sumur Bandung & $01.00-1800$ \\
5 & Gedebage & Jln Sukarno Hatta, Mekar Mulya, Penyileukan & 24 Jam \\
6 & Caringin & Jln Pasar Induk Caringin, Babakan Ciparay & 24 Jam \\
7 & Cihaurgeulis (Suci) & Jln Surapati, Sukaluyu, Cibuenying Kaler & $02.00-17.00$ \\
8 & Ujung Berung & Jln Raya Ujung Berung, Sukamulya, Cinambo & $22.00-17.00$ \\
9 & Gasibu & Jln Diponegoro, Citarum, Bandung Wetan & $06.00-12.00$ \\
10 & Ciroyom & Ciroyom, Andir & $05.00-19.00$
\end{tabular}

In addition to traditional markets, several streets in Bandung have become a foodscape stage for peddling Sundanese food, among of which famous ones are Cikapundung Street (Ceu Mar Warung), Serayu Street (Cuanki), Astina Street (Batagor Hanjuang), Jalan Trunojoyo (Bancakan), Jalan RE Martadinata, and Jalan Setiabudi (Surabi). Other locations that present Sundanese food exoticism are around Braga Street, Alun-alun, Tegalega, Taman Sari, Pasir Kaliki, Klenteng, Merdeka, Sukajadi, Ciumbuleuit, Cipaganti, Cisangkuy, Cibeunying (Jalan Ahmad Yani), Cikutra, Cilaki, and others. The sellers display new creations and innovations in serving food, either in appearance, taste, aroma, and so on. Various food festivals such as Braga Culinary Night, Keuken \#8 Festival, and others are held in those areas. Other Foodscape stages are on campuses such as UPI, UNPAR, STP Bandung, and others who often hold food festivals. Thus, the markets, the roads to the campuses in Bandung are the Sundanese gastronomic food landscape.

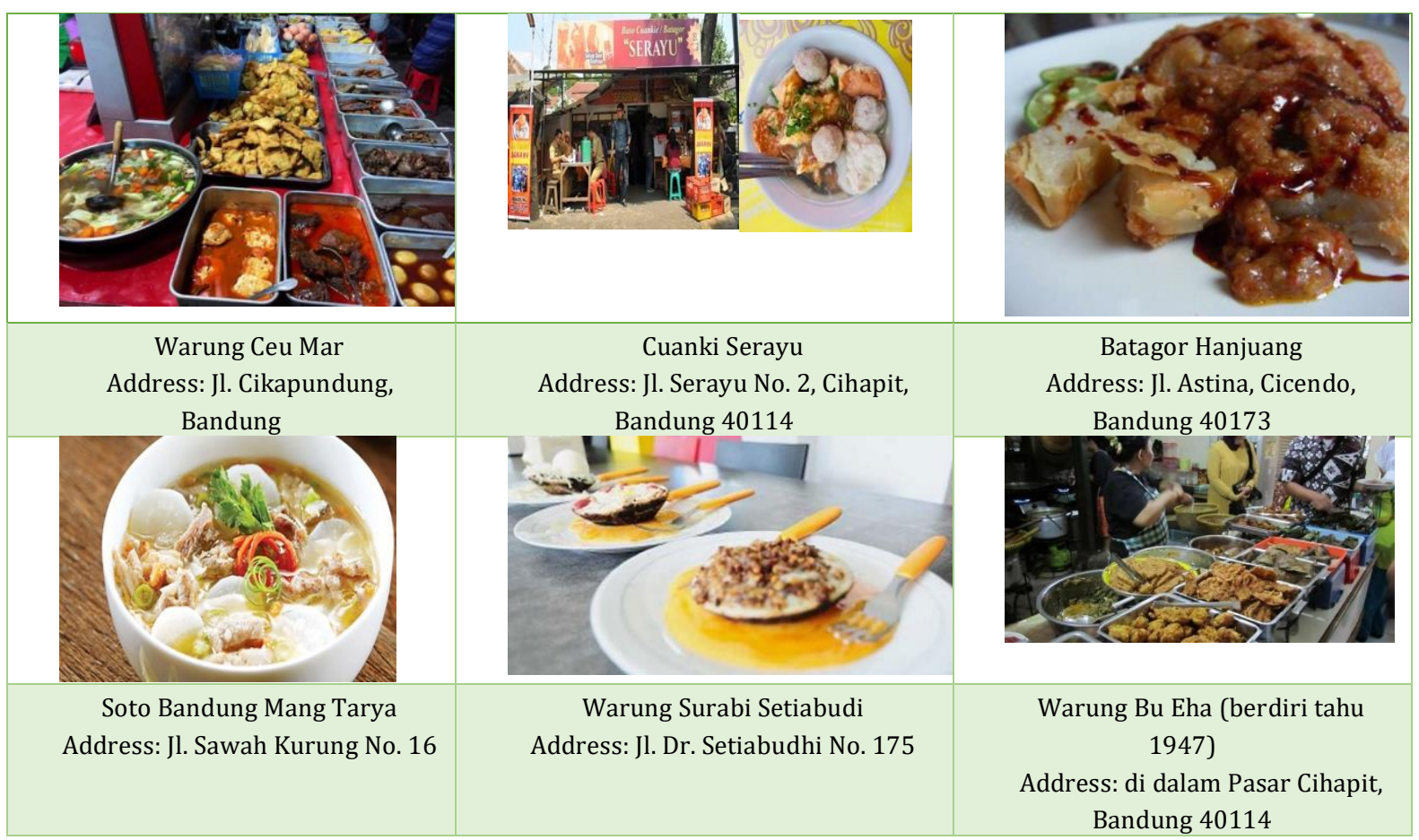




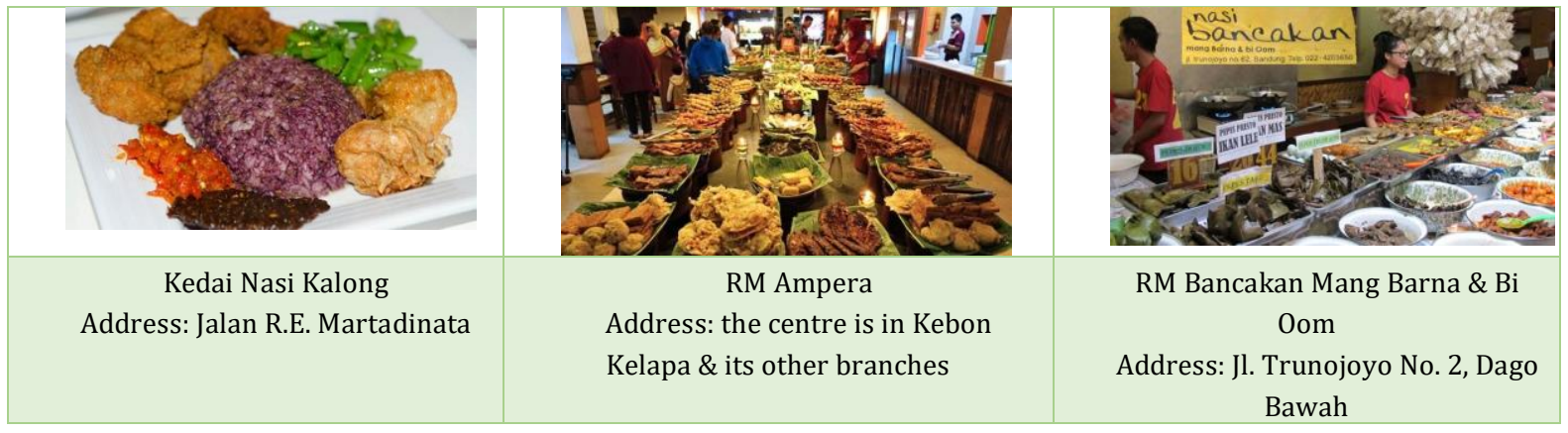

Fig. 2 Some Popular Foodscape in Bandung

Ceu Mar, a food outlet that opens at night by selling various dishes such as curry as the favorite, then also various vegetables, stir-fry, fried foods, meat, and other Sundanese style food. Meatballs and fried tofu (Batagor) Hanjuang have a distinctive taste compared to others because they use mackerel (tengiri fish) as raw material. Batagor is doused with thick peanut flavor with sweet and savory flavors and a sour taste that comes from lime juice. Cuanki looks like Bakso Malang (meatballs dish from Malang), but the contents are a mixture of meatballs, fried tofu, white tofu, and dumplings with a sauce that uses fishbone stew. Nasi Kalong (Kalong Rice), offered on Jalan R.E. Martadinata, comes from red rice cooked with kluwak or kepayang (Pangium edule) until the color is black so that it is personified like Kalong (Pteropus sp.) or a bat. Processing of this dish uses red chili (Capcicum annuum), coconut (Cocos nucifera), red onion (Allium cepa), and bay leaf (Syzygium polyanthum). The rice tastes fluffy and savory. Soto Bandung has a characteristic that is contrary to the general Soto dishes in Indonesia. Soto usually uses thick yellowish coconut milk from Kunyit (Curcuma longa). This dish contains a few pieces of chicken or beef, plus roasted soybeans (fried without oil), sliced-radish (Raphanus raphanistrum), and a sprinkling of celery leaves (Apium graveolens L.) with clear broth.

\subsection{The Flow of Food Ingredient from Origin to Bandung}

From the research, it was found that Bandung is a large foodscape with food sources either locally, regionally, or internationally. Many raw materials were brought in from the regions of West Java, Central Java, and East Java. In addition, those food ingredients were also supplied from Sumatra, Kalimantan, Sulawesi and some even had to be imported from China. West Java regions such as Sukabumi, Cianjur, Garut, Tasikmalaya, Clamis, Kuningan, Majalengka, Cirebon, Sumedang, Indramayu, Subang, Purwakarta, Karawang, Bekasi, and several other areas were the main suppliers of gastronomic needs to Bandung. Raw ingredient supplies included various types of vegetables, fruits, proteins, herbs, and carbohydrates (Fig. 3). Areas outside Java such as North Sumatra and West Sumatra were the suppliers of protein, carbohydrates, and fruits. From Jambi, Lampung, and Palembang many fruits and seasonings were sent to Bandung. Central Java and East Java were the suppliers of spices, fruits, carbohydrates, and protein. From abroad, many raw materials were imported from China, especially garlic (Fig. 4). 


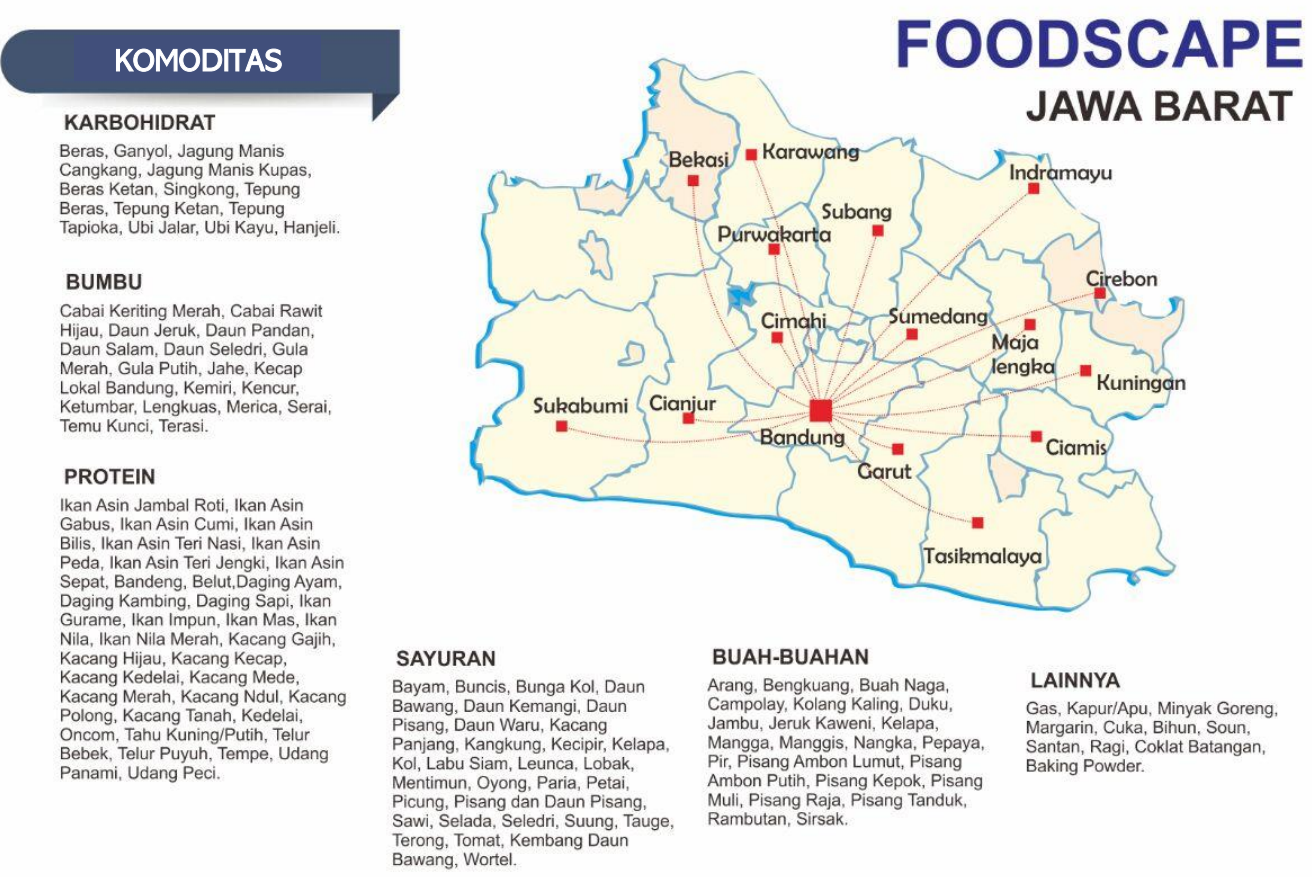

Fig. 3 Food Transmission from West Java to Bandung

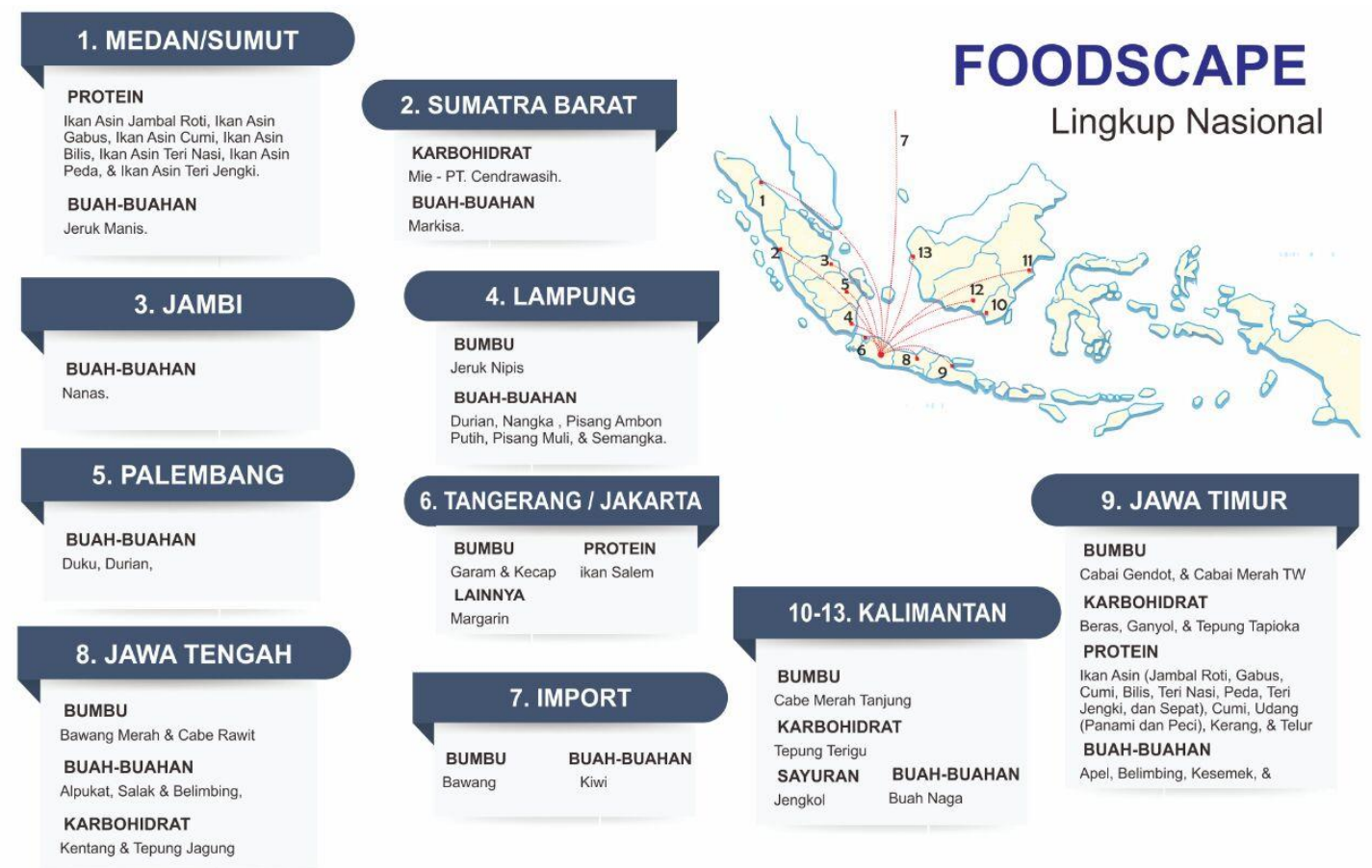

Fig. 4 Food Transmission from Other Region to Bandung

Thus it can be seen that foodscape is supplied with food sources from the foodshed. Conceptually, the foodshed or food transmission area to Bandung is analogous to the watershed which is a geographical location that produces food for a particular population. This term describes the flow of food from an area that acts as producers to other regions that become consumers, including the land where food is grown, the route or transmission, the market through which it passes, and the dining table as the estuary where the food flow ends (Foodshed Alliance Inc, 2018). The food supply is channeled through the local food network (LFN) starting from farmers, middlemen, collectors, using transportation business services, to 
wholesalers and retailers, before being distributed to consumers. With the exception of importers, the average number of business people who enter the LFN is classified as Micro, Small, and Medium Enterprises (MSMEs) and even many are small class. Another part of the entrepreneurs entered into Koperasi which later established the People's Owned Enterprises (BUMR) food. One of the food enterprises is domiciled in Sukabumi.

\section{Conclusion}

Based on the results of the research that has been done, the following conclusions can be drawn as follows:

1. Bandung is a foodscape as well as a Sundanese gastronomic estuary. In all areas of the city, there are stretches of food ranging from markets, sidewalks, stalls and restaurants, festival events to educational institutions that are an area to bring together Sundanese gastronomic products with its consumers.

2. Foodstuffs are delivered from foodshed around Bandung and other areas in West Java, also from the regions of Central Java, East Java, Sumatra, Kalimantan, Sulawesi, and some are sent from China namely garlic. Food raw materials are transmitted from sources in the West Java region through the local food network to Bandung.

Policy implications that can be recommended from the results of this study are as follows:

1. Bandung as a foodscape as well as the Sundanese gastronomic estuary needs to initiate an annual gastronomy event that carries a specific theme. The goal is not only to attract local consumers but also internationally. The form of this event must be iconic with the atmosphere of Tatar Pasundan.

2. It is necessary to make a gastronomy travel map which is disseminated through social media, pages (websites) and also tourism places or agents so that they can show or recommend tourists restaurants, types of food, processing, serving and also presenters as well as about the history of what and why there are restaurants and food, to architectural buildings and so on. This map of gastronomic trips can also be associated with foodshed around Bandung so that tourists can enjoy or see firsthand the process of breeding food raw materials. In short, this map of the gastronomic journey combines the beauty of the cultural landscape of Bandung and Sundanese food products.

\section{References}

BPS Kota Bandung. (2018). Statistik Sosial dan Kependudukan, Ekonomi dan Perdagangan, Pertanian dan Pertambangan. Retrieved August 17, 2018, from https://bandungkota.bps.go.id

Brembeck, H., \& Johansson, B. (2010). Foodscapes and children's bodies. Culture Unbound, 2, 797-818.

Brokaj, M. (2014). The Impact of the Gastronomic Offer in Choosing Tourism Destination: The Case of Albania. Academic Journal of Interdisciplinary Studies, 3(2), 249-256. https://doi.org/10.5901/ajis.2014.v3n2p249

Bryman, A. (2012). Social Research Method. Oxford: Oxford University Press.

Burgoine, T., Lake, A. A., Stamp, E., Alvanides, S., Mathers, J. C., \& Adamson, A. J. (2009). Changing foodscapes 1980-2000, using the ASH30 Study. Appetite, 53(2), 157-165. https://doi.org/10.1016/j.appet.2009.05.012

Currie, D. (2005). Developing and Applying Study Skills. London, UK: CIPD Enterprises Limited.

Dictionary.com. (n.d.). Value. Retrieved April 25, 2018, from http://www.dictionary.com/browse/value?s=t

Dolphijn, R. (2005). Foods Capes. Towards a Deleuzian Etics of Consumption. Delft: Eburon Publishers.

Edwards, F., \& Mercer, D. (2010). Meals in Metropolis: Mapping the urban foodscape in Melbourne, Australia. Local Environment, 15(2), 153-168. 
Foodshed Alliance Inc. (2018). Foodshed Alliance. Retrieved from http://foodshedalliance.org/

Freidberg, S. (2010). Perspective and power in the ethical foodscape. Environment and Planning, 42(8), 18681874.

Gebresenbet, G., \& Basola, T. (2012). Logistics and Supply Chains in Agriculture and Food. Retrieved from http://www.intechopen.com/download/pdf/pdfs_id/32382

Johnston, J., Biro, A., \& MacKendrick, N. (2009). Lost in the Supermarket: The Corporate-Organic Foodscape and the Struggle for Food Democracy. Antipode, 4l(3), 509-532. https://doi.org/10.1111/j.14678330.2009.00685.x

Kamus Besar Bahasa Indonesia. (n.d.). Kuliner. Retrieved August 17, 2018, from Retrieved Augustus website: https://azkamus.com/dictionary/kuliner

Karadeniz, M. (2009). The importance of retail site selection in marketing management and hypothetical approaches used in site selection. Journal of Naval Science and Engineering, 5(3), 79-90.

Knasko, S. C., Gilbert, A. N., \& Sabini, J. (1990). Emotional State, Physical Well-Being, and Performance in the Presence of Feigned Ambient Odor1. Journal of Applied Social Psychology, 20(16), 1345-1357. https://doi.org/10.1111/j.1559-1816.1990.tb01476.x

Lilholt, A. (2015). Entomological Gastronomy. North Carolina, USA: Lulu.com.

Manolis. (2010). Culinary tourism destination marketing and the food element: a market overview. Retrieved from https://aboutourism.wordpress.com/tag/culinary-tourism/

Mason, M. C., \& Paggiaro, A. (2012). Investigating the role of festivalscape in culinary tourism: The case of food and wine events. Tourism Management, 33(6), 1329-1336. https://doi.org/10.1016/j.tourman.2011.12.016

Pullphothong, L., \& Sopha., C. (2013). Gastronomic Tourism in Ayutthaya, Thailand. Bangkok, Thailand: School of Culinary Art, Suan Dusit Rajabhat University.

Santich, B. (1996). Looking for Glavour. Kent Town, South Australia: Wakefield Press.

Shenoy, S. (2005). Food Tourism and The Culinary Tourist. USA.

Sobal, J., \& Wansink, B. (2007). Kitchenscapes, Tablescapes, Platescapes and Foodscapes: Influences of Microscale Built Environments on Food Intake. Environment and Behavior, 39(1), 124-142. Retrieved from https://doi.org/10.1177

Soeroso, A. (2014). Foodscape, Cultural Landscape dan Arkeologi: Sebuah Upaya Pelestarian Cagar Budaya dan Pembangunan Ekonomi Indonesia. Konggres IAAI (Ikatan Ahli Arkeologi Indonesia). Kota Yogyakarta.

Soeroso, A., \& Susilo, Y. S. (2013). Traditional Indonesian Gastronomy as a Cultural Tourist Attraction. Journal Applied Economics for Developing Countries (JAEDC), 1, 1-28.

Somekh, B., \& Lewin, C. (2004). Research Method in the Social Science. Los Angeles: Sage Publications, Ltd.

Sumaryadi, \& Pah, J. G. (2010). Kajian Wisata Kuliner Kota Bandung. Jurnal Kepariwisataan Indonesia, 5(4), 473-492.

Thorne, S. (2001). The Okanagan cultural corridor newsletter. Retrieved from http://collections.ic.gc.ca/okanaganvalley

Turgarini, D., \& Soeroso, A. (2014). The development of traditional Indonesia gastronomy. 3rd International Congress UNITWIN Network UNESCO CHAIR “Culture, Tourism, Development." Barcelona, Catalonia, Spanyo: Tourism and Gastronomy Heritage: Foodscapes, Gastroregions and Gastronomy Tourism in 
Universitat de Barcelona.

Winson, A. (2004). Bringing Political Economy into the Debate on the Obesity Epidemic. Agriculture and Human Values, 21, 299-312.

Zukin, S. (1991). Landscapes of Power: From Detroit to Disney World. Berkeley: University of California Press. 